Journal of Agricultural Sciences
(Tarim Bilimieri Dergisi)

\title{
Competition-Productivity Relationship Between Some Common Grasses and Forbs Plant Species in High Altitude Rangelands
}

\author{
Sule ERKOVAN ${ }^{\text {** }}$, Ali KOC ${ }^{\text {(D) }}$

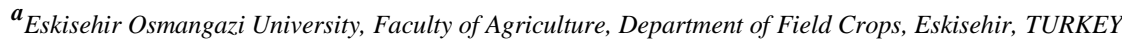 \\ ARTICLE INFO \\ Research Article \\ Corresponding Author: Sule ERKOVAN, E-mail: serkovan@ogu.edu.tr \\ Received: 16 March 2020 / Revised: 12 May 2020 / Accepted: 19 May 2021 / Online: 25 March 2022
}

\section{ABSTRACT}

Facilitation or competition occurs among plant species when one species alter ameliorates the environment for another species or when one species needs the same sources of another species. The objective of this study was to determine to facilitative or competitive effect on Bromus variegatus, Festuca ovina, Koeleria cristata of growing with isolated, Medicago papillosa, Astragalus microcephalus, Thymus parviflorus, and Hypericum scabrum, and arranged in completely randomized design. Plant height, above-and belowground biomass, and above-and belowground Relative Neighbour Effect (RNE) significantly affected main, some first- and second-order interaction depending on the year, grasses species, surrounding. Aboveground biomass increased in grasses, which grow in interaction with legume species, and significant differences were determined between the grass species and years. While average belowground biomass was $26,66 \mathrm{~g} / \mathrm{plant}$, the belowground biomass of the grass species grown in interaction with $M$. papillosa and A. microcephalus was positively affected and it was 31,58 and 34,99 $\mathrm{g} / \mathrm{plant}$, respectively. A. microcephalus had a facilitative effect on above ground RNE of the grass species and the other species had a competitive effect. All plant species had a competitive effect on belowground RNE.

Keywords: Facilitation, Competition, Plant-plant interaction, Plant environment

(C) Ankara University, Faculty of Agriculture

\section{Introduction}

Rangelands are an important component of farming systems in the Eastern Anatolia region of Turkey for centuries. The majority of studies on rangelands are focused on grazing effect, botanical composition, carrying capacity, and rangeland condition. The species relationships in these areas, consist of many different species, did not mostly take into account. Plant species can decrease or increase abundance on the rangelands depend on grazing, climatic change, and plant-plant interactions. Biotic interactions play an important role in the botanical composition of rangelands, influencing the abundance of species. The botanical composition consists of abundant and sparse species as a result of combinations of biotic interactions (Brooker 2006; Erkovan et al. 2008a; Grant et al. 2014). Biotic interactions among species are described by positive (facilitation), negative (competition), and neutral effect (Oksanen et al. 2006; Lutscher \& Iljon 2013). Consequently, vegetation structure and composition alter depending on changing these relationships (Tilman 1987).

Rangelands have a lively and dynamic structure consisting of many species. The details of these interactions are still not clear, particularly concerning the effects of the forbs, shrubs, and woods on grass growth and species composition. Plant facilitates other plants especially $\mathrm{N}_{2}$ fixing plants both directly and actively by ameliorating harsh environmental conditions, by altering soil properties, or by increasing availability of resources (Kurokawa et al. 2010), and also some plant species could be altered in their surrounding microsites of soil environment by inhibiting nitrification process (Ehlers et al. 2014). Plant species improve the micro climatic condition, organic matter content, microorganism, and water availability in the neighbour plant species-environment (Forey et al. 2010; Castanho et al. 2015). As a result of these processes, plant competition intensity modified and altered the community structure. Relative frequency of facilitation and competition will inversely proportional gradients of ecosystem productivity (Bertness \& Callaway 1994).

Plant-plant interaction and neighbour or target plants are explained by the stress gradient hypothesis (SGH). The balance of facilitation, competition, and neutral effect may be influenced to plant density, physiology, life stage, and invasion properties of species (Grant et al. 2014). Among plant species have reciprocal competition and have contrasting growth forms. Because of different root niches, plant species are assumed to be able to valuable water and mineral nutrition from lower soil layers than grasses (Cramer et al. 2010; Koc et al. 2013a). Negative effects include suppression of seed germination, seedling growth, and survival, but these effects change the life stages of plant species (Callaway \& Walker 1997). For example, adult plant species facilitate seedling but compete with other adult plant species as a result of these effects, target plants have a facilitative, 
competitive, or neutral effect on growth and yields (Castanho et al. 2015). Environmental and physical conditions restrict resource acquisition and the effect of the neighbour on the target plant becomes more severe, and competitive (Callaway 2007; Koc et al. 2008). Competition increase monotonically with increasing environmental severity. These complex interactions among plant species determine whether positive or negative and composition changes depending on the effect of direction. This complex effect contributes to the development of vegetation by affecting the existence, invasive nature, and production of species in vegetation.

Understanding the role of grasses and forb interactions in the alpine zone is important for botanical composition and rangeland management strategies. Therefore, we tested the effect of dominant plant species that two legumes forb and two the other families species forb interaction dominate grasses species in the alpine rangelands.

\section{Material and Methods}

The experiment was carried out on the Palandoken Mountain rangelands, where has been protected from grazing for afforestation by the Erzurum Sky Centre Office for more than 30 years, during 2013 and 2014. It has a 10\% slope, north aspect, and elevation of $2200 \mathrm{~m}$. The mean annual temperature and mean annual precipitation were $5.1{ }^{\circ} \mathrm{C}$ and $391.6 \mathrm{~mm}$, respectively. The average temperature was 5.3 and $7.7^{\circ} \mathrm{C}$ and total annual precipitation were 284.2 and $419.5 \mathrm{~mm}$ in 2013 and 2014, respectively (Table 1). The soil characteristics are taken around isolated, M. papillosa, A. microcephalus, T. parviflorus, and H. scabrum were determined to soil texture, sandy, clay, loam, electrical conductivity (EC), pH in soil saturation extract, Olsen phosphorus (P) contents, organic matter (OM), $\mathrm{CaCO}_{3}$, and aggregate stability (AS) as described by Soil Survey Laboratory Staff (1992) and presented in Table 2. The soil properties had differed greatly depending on isolated, M. papillosa, A. microcephalus, T. parviflorus, and H. scabrum.

Table 1- Some meteorological data of the Erzurum province during in the experiment years 2013, 2014 and long term average (LTA)

\begin{tabular}{lcccccc}
\hline \multicolumn{1}{c}{ Month } & \multicolumn{3}{c}{ Monthly Total Precipitation $(\mathrm{mm})$} & \multicolumn{3}{c}{ Monthly Air Temperature $\left({ }^{\circ} \mathrm{C}\right)$} \\
\hline January & 2013 & 2014 & LTA & 2013 & 2014 & LTA \\
February & 28.7 & 11.3 & 16.5 & -9.5 & -10.1 & -10.6 \\
March & 28.5 & 8.0 & 20.3 & -7.4 & -4.5 & -9.1 \\
April & 30.9 & 47.1 & 35.5 & -0.8 & 2.7 & -2.5 \\
May & 36.3 & 34.0 & 58.1 & 7.2 & 7.7 & 5.4 \\
June & 36.3 & 115.9 & 67.5 & 11.6 & 11.7 & 10.5 \\
July & 32.3 & 24.5 & 40.9 & 15.0 & 15.9 & 14.9 \\
August & 25.1 & 44.7 & 25.3 & 19.4 & 21.2 & 19.2 \\
September & 7.8 & 4.8 & 14.1 & 19.5 & 22.2 & 19.4 \\
October & 13.6 & 47.7 & 21.0 & 13.6 & 15.4 & 13.9 \\
November & 16.8 & 51.6 & 43.3 & 6.0 & 8.8 & 7.7 \\
December & 19.6 & 17.2 & 27.4 & 2.3 & 1.3 & 0.0 \\
\hline Total/Av. & 8.3 & 12.7 & 21.8 & -13.4 & -0.2 & -7.2 \\
\hline
\end{tabular}

Table 2- General physical and chemical properties of the experimental soils

\begin{tabular}{|c|c|c|c|c|c|c|c|c|c|c|}
\hline Plants & Texture & $\begin{array}{c}\text { Sandy } \\
(\%)\end{array}$ & $\begin{array}{c}\text { Clay } \\
(\%)\end{array}$ & $\begin{array}{c}\text { Loam } \\
(\%)\end{array}$ & $\begin{array}{c}E C \\
(\mu m h o s / c m)\end{array}$ & $p H$ & $\begin{array}{c}\mathrm{P}_{2} \mathrm{O}_{5} \\
(\mathrm{~kg} / \mathrm{da})\end{array}$ & $\begin{array}{l}O M \\
(\%) \\
\end{array}$ & $\begin{array}{c}\mathrm{CaCO}_{3} \\
(\%)\end{array}$ & $\begin{array}{l}A S \\
(\%) \\
\end{array}$ \\
\hline Isolated & Loamy & 42.25 & 35.61 & 22.15 & 225.82 & 6.20 & 5.96 & 5.77 & 0.39 & 79.61 \\
\hline M. papillosa & Loamy & 44.14 & 36.09 & 19.78 & 257.48 & 6.14 & 12.73 & 6.61 & 0.38 & 81.70 \\
\hline A. microcephalus & Loamy & 41.52 & 37.42 & 21.08 & 269.00 & 6.22 & 10.96 & 7.69 & 0.35 & 83.00 \\
\hline T. parviflorus & Loamy & 45.26 & 34.72 & 20.03 & 241.75 & 6.14 & 11.28 & 7.03 & 0.44 & 83.38 \\
\hline H. scabrum & Loamy & 43.59 & 36.05 & 20.38 & 226.07 & 6.13 & 6.72 & 5.85 & 0.40 & 84.32 \\
\hline Average & & 43.35 & 35.98 & 20.68 & 244.02 & 6.17 & 9.47 & 6.59 & 0.39 & 82.40 \\
\hline
\end{tabular}

EC: Electrical conductivity, OM: organic matter, AS: aggregate stability

The area covered by shortgrass steppe vegetation, of which common plant species with more than $1 \%$ in the botanical composition are Bromus variegatus, Festuca ovina, Koeleria cristata, Phleum montanum, for Poaceae; Astragalus microcephalus, Astragalus lineatus, Medicago papillosa for legumes; Alyssum desertorum, Dianthus multicaulis, Galium verum, Hypericum scabrum, Plantago lanceolata, Thymus parviflorus and Ziziphora persica for the other families. At the beginning of the growing seasons, three wide-spread types of grass species (F. ovina, B. variegatus, and K. cristata) were chosen and marked to investigate their relation with $M$. papillosa, A. microcephalus, T. parviflorus, and $H$. scabrum which are common forbs in the rangelands. Ten grass and forb for every species were matched grown in $10 \mathrm{~cm}$ periphery. There was no other plant closer than $0.5 \mathrm{~m}$ to avoid inter-and intra-specific interaction. If there were more plants belong to investigated species in $0.5 \mathrm{~m}$ peripheries were removed by clipping the ground. To understand the intra-specific interaction between investigated species, ten sole grown plants for each grass species were selected. While selecting grasses plants are considered 
as possible as similar age and canopy size. Consequently, the experiment was arranged completely randomized design with 10 replications.

When investigated grasses reached full flowering stage (beginning of July), firstly plant height was measured, thereafter, the plants were excavated using trench method, with the peripheral trench being $25 \mathrm{~cm}$ in width and $30 \mathrm{~cm}$ in depth where $90 \%$ of the root mass was produced (Manning et al. 1989; Gokkus \& Koc 1996). The soil on the roots was separated by hand, thereafter, transported laboratory with paper bag, plant roots were separated from soil by washing off under tap water. Thereafter, plants were separated into above- and belowground parts by cutting at crown level. The samples were dried in the oven at $65{ }^{\circ} \mathrm{C}$ to constant weight and weighed. Relative neighbour effect (RNE) was determined from the dry mass both above- and belowground biomass following equations by using (Oksanen et al. 2006).

\section{$\mathrm{RNE}=(\mathrm{Wr}-\mathrm{Wc}) / \max (\mathrm{Wr}, \mathrm{Wc})$}

Where; RNE, is the relative neighbour effect $(-1 \leq \mathrm{RNE} \leq+1), \mathrm{Wr}$ is the performance of manipulated plants; Wc, is the performance of isolated. This index compares the above- and belowground biomass of $F$. ovina, B. variegatus, and K. cristata with that grown as isolated and in the M. papillosa, A. microcephalus, T. parviflorus, and H. scabrum. Negative and positive values indicate respectively competition and facilitation by neighbours.

The same procedure was also repeated in the second experimental years. We performed the analysis of variance considering based on General Linear Model (GLM) for a completely randomized design using StatView package (SAS Institute 1998). Multiple comparisons with Bonferroni/Dunn were used to determine the effect of grasses species, year and growing isolated and interaction within under M. papillosa, A. microcephalus, T. parviflorus, and H. scabrum plant species on the above- and belowground biomass and RNE.

\section{Results}

Under natural conditions, the plant height of grasses species changed significantly depending on years, grasses, and surroundings. It was higher in 2013 than in 2014 (Table 3 Among the grasses species, plant height varied from $33.35 \mathrm{~cm}$ to $52.30 \mathrm{~cm}$ and B. variegatus had the highest plant height (Table 3). The grasses species growing with A. microcephalus had higher plant height than the others $(\mathrm{P}<0.001)$. Except for $B$. variegatus, plant height of $F$. ovina and $K$. cristata varied significantly according to years, and both growing surrounding. For example, the height of $F$. ovina growing with $H$. scabrum was higher in 2013, but it was the lowest in 2014. While plant height of $K$. cristata growing with $H$. scabrum was the lowest in 2013, the highest in 2014. Hence, Y x S and Y x G x S interactions were significant for the plant height (Figure 1).

Table 3- Plant height, above- and belowground biomass, above- and belowground RNE the means of grasses species growing with isolated and forb plant species and their ANOVA results

\begin{tabular}{|c|c|c|c|c|c|}
\hline Treatments & $\begin{array}{c}\text { Plant } \\
\text { Height }\end{array}$ & $\begin{array}{c}\text { Aboveground } \\
\text { Biomass }\end{array}$ & $\begin{array}{c}\text { Belowground } \\
\text { Biomass } \\
\end{array}$ & $\begin{array}{c}\text { Aboveground } \\
\text { RNE }\end{array}$ & $\begin{array}{c}\text { Belowground } \\
\text { RNE } \\
\end{array}$ \\
\hline \multicolumn{6}{|l|}{ Years (Y) } \\
\hline 2013 & $45.07 \mathrm{~A}$ & $9.91 \mathrm{~A}$ & $34.51 \mathrm{~A}$ & $0.006 \mathrm{~A}$ & $0.089 \mathrm{~A}$ \\
\hline \multicolumn{6}{|l|}{ Grasses (G) } \\
\hline$F$. ovina & $33.35 \mathrm{C}$ & $7.76 \mathrm{~B}$ & $29.02 \mathrm{~B}$ & $-0.006 \mathrm{~A}$ & -0.166 \\
\hline \multicolumn{6}{|l|}{ Surrounding (S) } \\
\hline Isolated & 41.18 BC & $6.63 \mathrm{AB}$ & $24.02 \mathrm{~B}$ & - & - \\
\hline M. papillosa & $41.38 \mathrm{~B}$ & $7.38 \mathrm{~A}$ & $31.58 \mathrm{AB}$ & $-0.102 \mathrm{AB}$ & $-0.050 a$ \\
\hline A. microcephalus & $45.25 \mathrm{~A}$ & $8.31 \mathrm{~A}$ & $34.99 \mathrm{~A}$ & $0.023 \mathrm{~A}$ & $-0.030 \mathrm{a}$ \\
\hline T. parviflorus & $39.58 \mathrm{BC}$ & $5.51 \mathrm{~B}$ & $21.34 \mathrm{C}$ & $-0.191 \mathrm{~B}$ & $-0.150 a b$ \\
\hline G & $* *$ & $* *$ & $* *$ & $* *$ & ns \\
\hline $\mathrm{S}$ & $* *$ & $* *$ & $* *$ & $* *$ & $*$ \\
\hline$Y \times G$ & ns & $* *$ & $* *$ & $* *$ & $* *$ \\
\hline $\mathrm{Y} \times \mathrm{S}$ & $*$ & $* *$ & $* *$ & ns & ns \\
\hline $\mathrm{G} \times \mathrm{S}$ & ns & $* *$ & $* *$ & $* *$ & $* *$ \\
\hline$Y \times G \times S$ & $*$ & $*$ & $*$ & $*$ & $*$ \\
\hline
\end{tabular}

Values followed by small and capital in a column shows significantly differences at $\mathrm{P}<0.05$ and $\mathrm{P}<0.01$ levels, respectively 


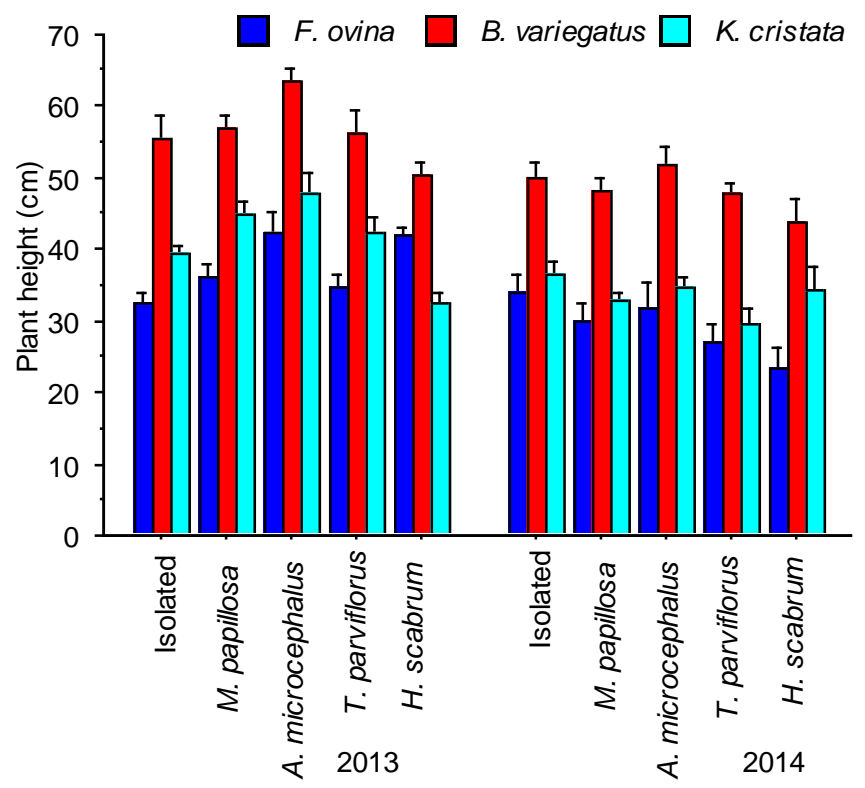

Figure 1- Growing with isolated and forb plant species first and second order interaction on plant height of grasses species

In the experiment, the main effect of year, grasses species ( $F$. ovina, B. variegatus, and K. cristata), surrounding (isolated, M. papillosa, A. microcephalus, T. parviflorus, and H. scabrum), and all first second-order interaction was significant for above- and belowground biomass (Table 3). Above- and belowground biomass of grasses species decreased in the 2014 year compared to 2013 (Table 3). Above- and belowground biomass of F. ovina, B. variegatus, and K. cristata were above- 7.76, $11.91,0.84 \mathrm{~g} /$ plant, and belowground 29.02, 47.58, and $3.39 \mathrm{~g} / \mathrm{plant}$, respectively (Table 3 ). The average aboveground biomass of grasses species was $6.83 \mathrm{~g} / \mathrm{plant}$, and growing with isolated, M. papillosa, A. microcephalus, T. parviflorus, and H. scabrum were 6.63, 7.38, 8.31, 5.51, and 6.34 g/plant, respectively (Table 3). Belowground biomass was higher for growing with A. microcephalus than the other but there was no difference among M. papillosa (Table 3). Both aboveground and belowground biomass showed strong variation among years, grasses species, and growing surrounding. As a result of this variation, all the main effects as well as the first and second-order interaction were significant (Figures 2 and 3).

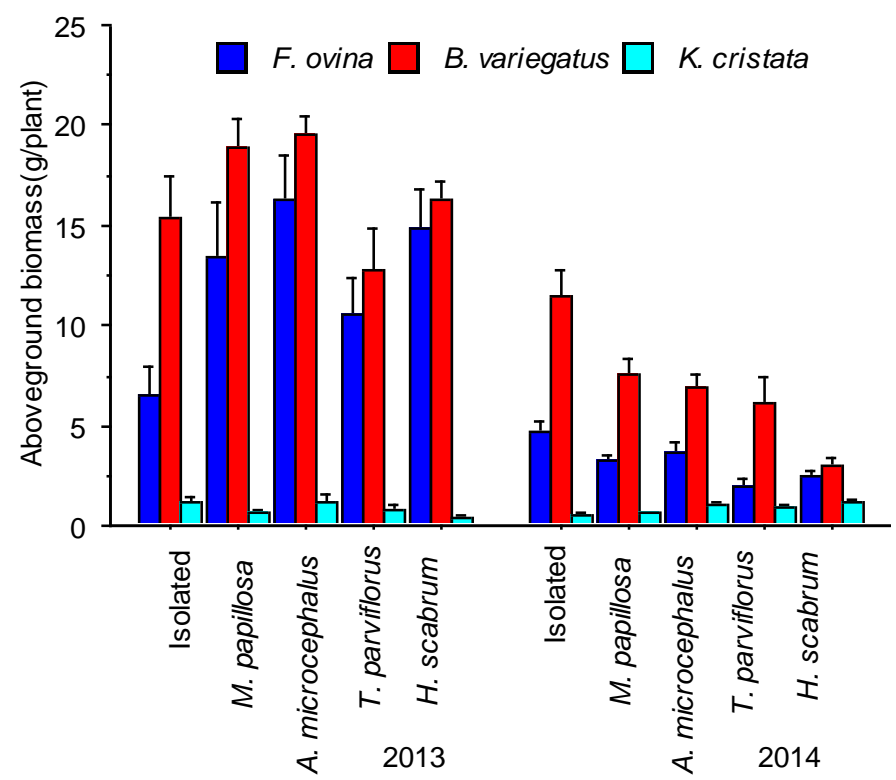

Figure 2- Growing with isolated and forb plant species first and second order interaction on aboveground biomass of grasses species 


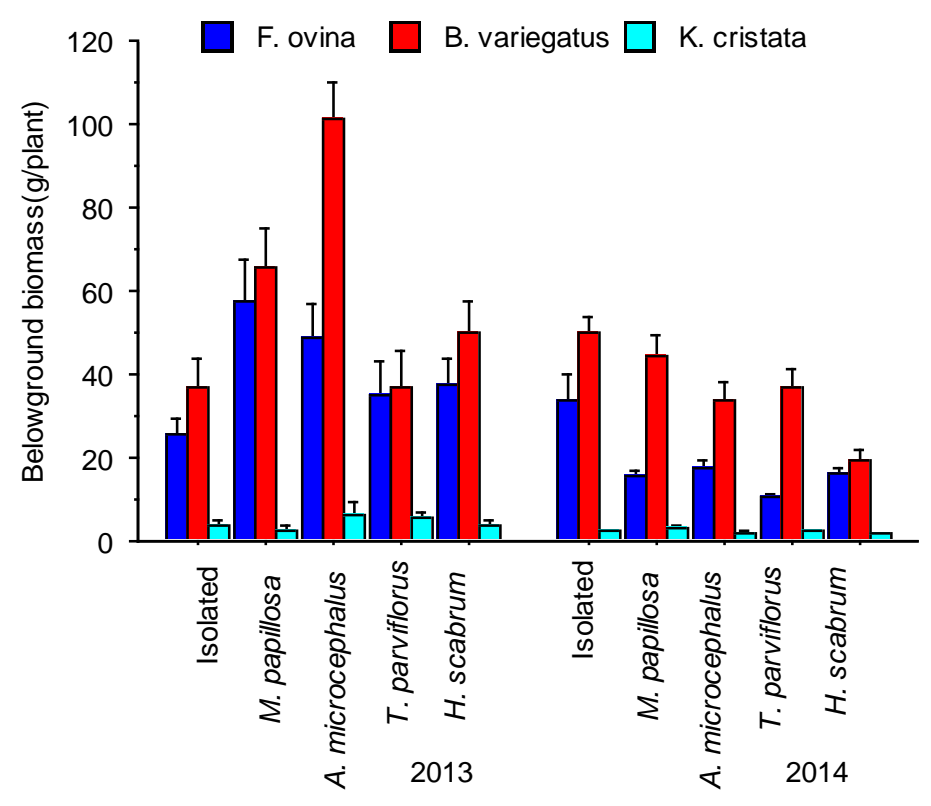

Figure 3- Growing with isolated and forb plant species first and second order interaction on belowground biomass of grasses species

Grasses species were significantly facilitated by neighbour plants in 2013, but this effect turned to competition in 2014 on both above- and belowground RNE (Table 3). Grasses species had negative above- and belowground RNE values and aboveground RNE was significant but belowground RNE was not significant (Table 3). RNE on aboveground growth of grasses species was significantly competed by neighbour plants, the highest negative RNE value was recorded in B. variegatus. RNE on belowground growth of grasses species was not significantly affected by neighbour plants, but all grasses species had negative RNE values. Grasses species growing with isolated, M. papillosa, A. microcephalus, T. parviflorus, and H. scabrum significantly affected both above- and belowground RNE. Grasses species were facilitated on aboveground RNE by $A$. microcephalus and competed by the others but belowground RNE competed for all of them (Table 3). Except for Y $\mathrm{x} S$ interaction, the other first and second-order interactions were significant for above- and belowground RNE. Both above- and belowground RNE varied greatly according to the years, grasses species, and surrounding (Figures 4 and 5). For example, $B$. variegatus aboveground RNE was facilitated by $M$. papillosa, A. microcephalus, and $H$. scabrum but competed by $T$. parviflorus in 2013, thereafter, it competed for all of in 2014 and a similar result was also observed belowground RNE (Figures 4 and 5). Hence, first and second-order interactions were significant for above- and belowground RNE, except for Y $\mathrm{x}$ $\mathrm{S}$ interaction.

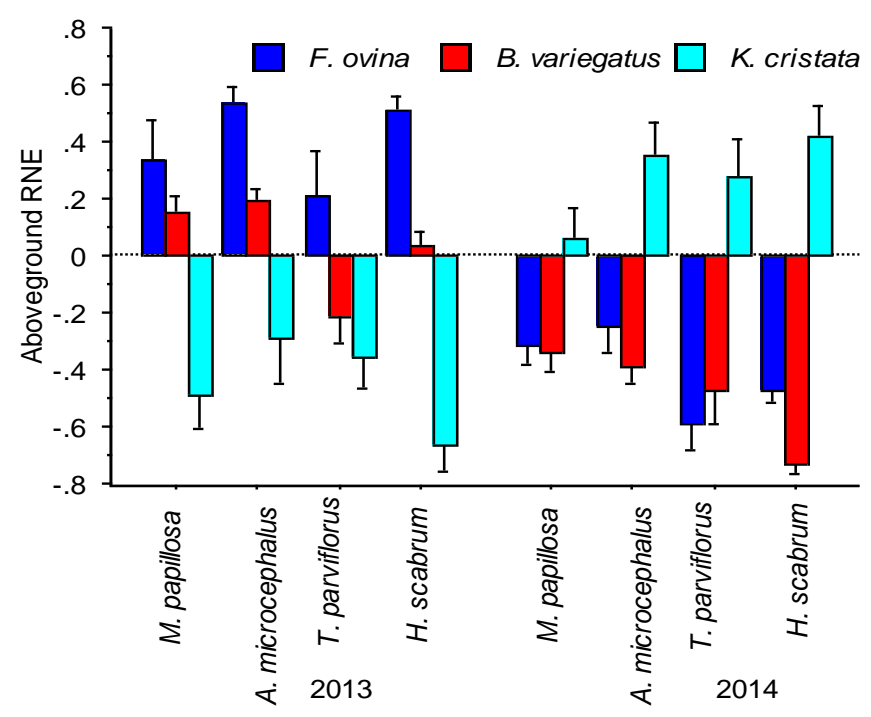

Figure 4- Growing with M. papillosa, A. microcephalus, T. parviflorus and H. scabrum first and second order interaction on aboveground RNE of grasses species 


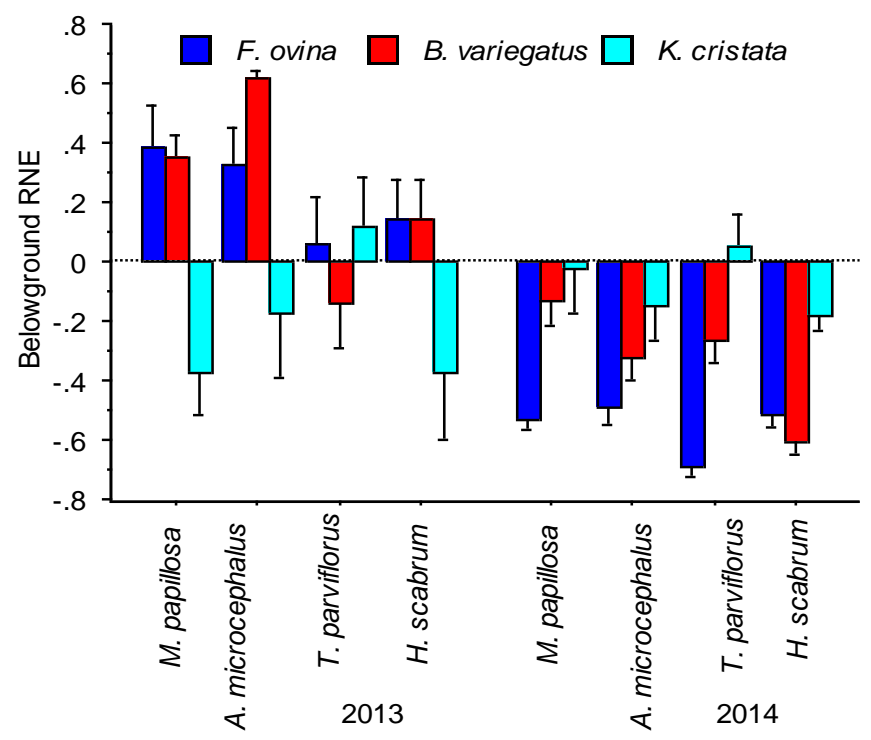

Figure 5 - Growing with M. papillosa, A. microcephalus, T. parviflorus and H. scabrum first and second order interaction on belowground RNE of grasses species

\section{Discussion}

Plant height, above- and belowground biomass of the grasses species was affected significantly by years, grasses species, and surrounding (isolated or interaction within under $M$. papillosa, A. microcephalus, T. parviflorus, and $H$. scabrum plant species). In the main effects, the differences among grass species will not be discussed ongoing text because the main reason for these differences stemmed from their genetic differences. Cool-season grasses, which need vernalization for reproduction showed a good response preceding autumn precipitation (Koc 2001). Preceding autumn of the first year received plenty of precipitation (41,7 mm only in October; non-presented data) and this precipitation support autumn regrowth of grasses. On the other hand, late autumn and winter precipitation accumulated in the soil in the cool climate, and it support plant growth during the following growing season. Hence, grasses produced more biomass in the first experimental year, which dried than in the second year. Since the first experimental year autumn received limited precipitation and it did not support the regrowth of grasses, therefore, grasses produced less biomass in the second year. Plant height results also support the above-mentioned interpretation.

Plant species can be affected by grasses in a facilitative or competitive way depending on the associated plant. The facilitative effect occurs especially in dry environments rather than humid or wet environments and it is more pronounced if associated plants have the nitrogen-fixing ability (Eldridge et al. 2011; Blaser et al. 2013; Sitters et al. 2013). Above- and belowground production results showed that A. microcephalus and M. papillosa have a facilitative effect on the neighbour grasses. This situation must be originated from these two neighbours of the grasses being nitrogen-fixing ability because the plant has the ability of nitrogen fixation provide a facilitative effect on neighbour plants under favourable condition (Table 2) (Erkovan et al. 2008b; Eldridge et al. 2011; Blaser et al. 2013; Sitters et al. 2013). The relation was neutral with H. perforatum but competitive with $T$. parviflorus with respect to above- and belowground production. Competitive effects occurred in $T$. parviflorus and neighbour grasses must probably be originated form it's allelopathic effect because T. parviflorus have a strongly allelopathic effect, especially, it causes nitrogen deficiency due to decreasing microbial activity of nitrogen released microorganism (Abdul-Rahman \& Habib 1989; Small et al. 1990).

The grasses did not show the same relation trend with neighbour plants in both years. The main reason for these differences should be originated from the discrepancy in climate pattern between the years because preceding autumn and winter received plenty of precipitation in the first year which supports the growth of the plants at the beginning of the growing season while received lower precipitation in the same period in the second years. In the experiment, the neighbour plants are broadleaved and have taproot systems. This root system used efficiently the moisture stored in the deep soil layer which is carried upper layer by capillarity than fibrous root system (Kiaer et al. 2013; Liu et al. 2013), consequently, since ceased moisture transport from the deeper layer to the upper layer, the grasses grown with broadleaved neighbour plants must have lived serious moisture stress than grown without broadleaved neighbour (Ludwig et al. 2003; Li et al. 2006; Herben et al. 2007; Wang et al. 2014). Thus, the grasses have grown together broadleaved neighbours produced less above- and belowground biomass than isolated grasses. Hence, the interaction related to years was significant in the experiment. Although it was not clear as in above- and belowground production, a similar shift was observed also plant height (Figure 1). 
Environmental factors, especially climate, significantly affect plant-environment relations (Koc et al. 2013b; Grant et al. 2014). In the first year, RNE was about neutral for aboveground growth while it was slightly positive for belowground growth. Whereas it was negative for both properties in the second year. This incompatible situation must be originated the differences in the soil water regime of the beginning of the growing season between the years. Because the precipitation preceding period of the first year's growing season provides sufficient water storing in the root zone, it was not limited due to insufficient precipitation preceding the second year's beginning of the growing season. Broadleaved plants used available water from deeper soil layer before reaching grasses root zone by capillarity (Ludwig et al. 2003; Torres \& Montana 2015; Soliveres et al. 2015), hence, grasses lost competitive advantage due to water stress and consequently, RNE for both above- and belowground growth were negative in the second year (Table 3).

Aboveground competition performance was more severe for B. variegatus than the other. The main reason for this situation must be originated from water deficiency at the beginning of the growing season in the second year because the plant showed partly positive competition performance in the first year (Figure 4). Because this plant has large habitus and need more water during the life cycle than the others and competitive effect of the plants alters with changing environmental condition. Water shortage at the beginning of the growing season in the second year causes the loss of the competitive advantage of $B$. variegatus. This result implied that $B$. variegatus can be eliminated from natural vegetation in the future if moisture deficiency stress increases due to global warming. This opposite response of B. variegatus with respect to aboveground competition to years also causes interactions including years. Another reason is this interaction was related to K. cristata's response to years. This plant has small habitus and maturates earlier (Arnow 1994), therefore, avoids drought easily. Under this condition, the plant loses competition advantage under a longer growing season, whereas, this growing trait provides a competitive advantage under a short growing season. For this reason, $K$. cristata showed a different competitive performance than the other two grass species. Consequently, these different responses of the grasses to both year and neighbour plants caused two and three-way interactions for aboveground growth.

The belowground competition was more vigorous than the aboveground (Wang et al. 2014). Thus, belowground competition, except for B. variegatus, the grasses more negatively than that of aboveground (Table 3 ). These effects were more pronounced in the second year due to the dry beginning of the growing season but the grasses were affected differently by neighbour plants and years. This situation was the main reason of two and three was interactions and were originated mainly changing of responses of the plants to changing environmental condition such as soil, water, neighbour plant, etc. (GarciaCervigon et al. 2013).

Competitive effect of neighbour broadleaves plants on the grasses changes among species. A. microcephalus, which is a member of Fabaceae, had an overall positive effect on the aboveground growth of grasses. This relation was positive for $F$. ovina and $B$. variegatus and was negative for $K$. cristata in the first year and these relations reversed back in the second year (Figure 4). A. microcephalus provide nitrogen to growing media, therefore the plant lived together with them can use this nitrogen, hence, aboveground growth of $F$. ovina and $B$. variegatus were affected positively in the first year since the plants absorbed enough water during the growing period. Whereas this two grasses species showed negative competitive performance concerning aboveground growth in the second year. This situation must be originated from water deficiency during the advanced period of the growing season because microbial nitrogen availability increases with the advanced season due to warming soil temperature (Erkovan 2007; Novoplansky \& Goldberg 2001; Anthelme \& Michalet, 2009), whereas, since water limitation restricts to plant growth, plants do not use available nitrogen because plants uptake nutrients by using water. As plants complete life cycle without stress under current condition, the plants complete their life cycle later suppress the plant which is complete life cycle earlier (Fabbro \& Prati 2015). Thus, K. cristata, which complete the growth cycle earlier, was affected negatively by other plants' competition performance with respect to aboveground growth. Whereas, the other plants encountered water stress during the growing season in the second year than did not showed normal growth performance but $K$. cristata complete the life cycle before the drought period. Consequently, K. critata showed positive competitive performance under dry conditions while it showed negative competitive performance under normal conditions. These results implied that increase in botanical composition in the future if precipitation patterns do not change positively under global warming conditions. Similar trends also occurred in the belowground competition performance of the plants (Figure 4).

M. papillosa also a member of Fabaceae but its positive effect on neighbour grasses was not clear as was A. microcephalus (Table 3, Figures 3 and 4) and its effect was generally negative due to its allelopathic properties (Abdul-Rahman \& Habib 1989; Small et al. 1990).

In conclusion, the dominant species of rangeland vegetation are species included in the Poaceae family. However, depending on the climate, environment, and usage conditions, a significant increase can be observed in Fabaceae or other families, and even these species may become dominant. The interactions between the species of Poaceae, Fabaceae, and other families that make up the rangeland vegetation affect the species composition and richness. For example, species included in the Fabaceae family can positively affect other plant species with nitrogen fixation, taproot, and root excretions. Another positive relationship between plants is stress tolerance. These biotic relationships between plants change according to climate, environment, and usage characteristics and this situation can change the structure and functions of pasture vegetation. There is a continuous interaction between the plant species, and this interaction can affect the plant's neighbour positively, negatively, 
or neutral. The relationship between plant species in the rangeland vegetation will undoubtedly provide important benefits in terms of fulfilling the functions of rangelands. Grasses species, their different reactions over the years, and interaction with other plant environments have been the main source of first and second-order interaction. Also, similar results have been recorded in other studies (Cavieres \& Sierra-Almeida 2012; Blaser et al. 2013; Ehlers et al. 2014; Grant et al. 2014).

\section{References}

Abdul-Rahman A A \& Habib S A (1989). Allelopathic effect of alfalfa (Medicago sativa) on bladygrass (Imperata cylindrica). Journal of Chemical Ecology 15: 2289-2300. https://doi.org/10.1007/BF01012082

Anthelme F \& Michalet R (2009). Grass-to-tree facilitation in an arid grazed environment (Air Mountains, Sahara). Basic and Applied Ecology 10: 437-446. https://doi.org/10.1016/j.baae.2008.10.008

Arnow L A (1994). Koeleria macrantha and K. pyramidata (Poaceae): Nomenclatural problems and biological distinctions. Systematic Botany 19: 6-20. https://doi.org/10.2307/2419708

Bertness M \& Callaway R M (1994). Positive interactions in communities. Trends in Ecology and Evolution 9: 191-193. https://doi.org/10.1016/0169-5347(94)90088-4

Blaser W J, Sitters J, Hart S P, Edwards P J \& Venterink H O (2013). Facilitative or competitive effects of woody plants on understorey vegetation depend on N-fixation, canopy shape and rainfall. Journal of Ecology 101: 1598-1603. doi: 10.1111/1365-2745.12142

Brooker R W (2006). Plant-plant interactions and environmental change. New Phytologist 171: 271-284. doi: 10.1111/j.14698137.2006.01752.x

Callaway R M (2007). Positive Interactions and Interdependence in Plant Communities. Springer Dordrecht, The Netherlands

Callaway R M \& Walker L R (1997). Competition and facilitation: a synthetic approach to interactions in plant communities. Ecology 78: 1958-1965. https://doi.org/10.1890/0012-9658(1997)078[1958:CAFASA]2.0.CO;2

Castanho C T, Oliveira A A \& Prado P I K L (2015). Does extreme environmental severity promote plant facilitation? An experimental field test in a subtropical coastal dune. Oecologia 178: 855-866. doi: 10.1007/s00442-015-3285-7

Cavieres L A \& Sierra-Almeida A (2012). Facilitative interactions do not wane with warming at high elevations in the Ands. Oecologia 170: 575-584. doi: 10.1007/s00442-012-2316-x

Cramer M D, Van Cauter A \& Bond W J (2010). Growth of $\mathrm{N}_{2}$-fixing African savanna Acacia species is constrained by below-ground competition with grass. Journal of Ecology 98: 156-167. https://doi.org/10.1111/j.1365-2745.2009.01594.x

Ehlers B K, Charpentier A \& Grondahl E (2014). An allelopathic plant facilitates species richness in the Mediterranean garrigue. Journal of Ecology 102: 176-185. https://doi.org/10.1111/1365-2745.12171

Eldridge D J, Bowker M A, Maestre F T, Roger E, Reynolds J F \& Whitford W G (2011). Impacts of shrub encroachment on ecosystem structure and functioning: towards a global synthesis. Ecology Letters 14: 709-722. https://doi.org/10.1111/j.1461-0248.2011.01630.x

Erkovan H I (2007). The determination of nitrogen fixation and transfer in legume and grasses mixtures. In: Turkish Field Crops Congress, 25-27 June, Erzurum, pp. 268-271

Erkovan H I, Gullap M K \& Gul I (2008a). Competition and succession in pastures, rangelands and forage crops. Alinteri Journal of Agriculture Science 14: 27-38. https://dergipark.org.tr/tr/download/article-file/26258

Erkovan H I, Tan M, Halitligil M B \& Kislal H (2008b). Performance of white-clover grasses mixtures: Part-I Dry matter production, botanical composition, nitrogen use efficient, nitrogen rate and yield. Asian Journal of Chemistry 20: 4071-4076

Fabbro C D \& Prati D (2015). The relative importance of immediate allelopathy and allelopathic legacy in invasive plant species. Basic and Applied Ecology 16: 28-35. https://doi.org/10.1016/j.baae.2014.10.007

Forey E, Touzard B \& Michalet R (2010). Does disturbance drive the collapse of biotic interactions at the severe and of a diversity-biomass gradient? Plant Ecology 206: 287-295 doi: 10.1007/s11258-009-9642-z

Garcia-Cervigon A I, Gazol A, Sanz V, Cameroro J J \& Olano J M 2013. Intraspecific competition replaces interspecific facilitation as abiotic stress decreases: The shifting nature of plant-plant interactions. Perspectives in Plant Ecology, Evolution and Systematics 15: 226-236. https://doi.org/10.1016/j.ppees.2013.04.001

Grant K, Kreyling J, Heilmeier H, Beierkuhnlein C \& Jentsch A (2014). Extreme weather events and plant-plant interactions: shifts between competition and facilitation among grassland species in the face of drought and heavy rainfall. Ecological Research 29: 991-1001. doi: $10.1007 / \mathrm{s} 11284-014-1187-5$

Gokkus A \& Koc A (1996). Canopy and root development of crested wheatgrass in relation to the quantity and time of nitrogen application. Tr. J. Agriculture and Forestry 20: 289-293

Herben T, Brezina S, Stanislav H, Hadincova V \& Krahulec F (2007). Variation in plant performance in a grassland: Species- specific and neighbouring root mass effects. Journal of Vegetation Science 18: 55-62. doi: 10.1111/j.1654-1103.2007.tb02515.x

Kiaer L P, Weisbach A N \& Weiner J (2013). Root and shoot competition: a meta-analysis. Journal of Ecology 101: 1298-1312. https://doi.org/10.1111/1365-2745.12129

Koc A (2001). Autumn and spring drought periods affect vegetation on high elevation rangelands of Turkey. J. Range Management 54: 622627. doi: $10.2307 / 4003594$

Koc A, Erkovan H I \& Serin Y (2008). Changes in vegetation and soil properties under semi-nomadic animal raising areas in highlands, rangelands of Turkey. Current World Environment 3: 15-20. doi: 10.12944/CWE.3.1.02

Koc A, Erkovan S, Erkovan H I, Oz U, Birben M M \& Tunc R (2013a). Competitive effects of plant species under different sowing ratios in some annual cereal and legume mixtures. Journal of Animal and Veterinary Advances 12: 509-520. doi: 10.36478/java.2013.509.520

Koc A, Gullap M K \& Erkovan H I (2013b). The soil seed bank pattern in highland rangelands of Eastern Anatolian Region of Turkey under different garzing systems. Turkish Journal of Field Crops 18: 109-117

Kurokawa H, Peltzer D A \& Wardle A (2010). Plant traits, leaf palatability and litter decomposability for co-occurring woody species differing in invasion status and nitrogen fixation ability. Functional Ecology 24: 513-523. https://doi.org/10.1111/j.13652435.2009.01676.x

Li L, Sun J, Zhang F, Guo T, Bao X, Smith F A \& Smith S E (2006). Root distribution and interactions between intercropped species. Oecologia 147: 280-290. doi: 10.1007/s00442-005-0256-4 
Liu G X, Zhang X J, Hovstad K A, Mao P S \& Han J G (2013). Competition of Leymus chinensis and Bromus inermis in response to gap size and neighbouring root exclusion. Grass and Forage Science 69: 479-487. https://doi.org/10.1111/gfs.12050

Ludwig F, Dawson T E, Kroon H \& Berendse F (2003). Hydraulic lift in Acacia tortilis trees on a EastAfrican savanna. Oecologia 134: 293300. doi: 10.1007/s00442-002-1119-x

Lutscher F \& Iljon T (2013). Competition, facilitation and the allee effect. Oikos 122: 621-631. https://doi.org/10.1111/j.16000706.2012.20222.x

Manning M E, Swanson S R, Svejcar T \& Trent J (1989). Rooting characteristics of four intermountain meadow community types. J. Range Management 42: 309-312

Novoplansky A \& Goldberg D (2001). Interactions between neighbour environments and drought resistance. J. Arid Environments 47: 11-32. https://doi.org/10.1006/jare.2000.0701

Oksanen L, Sammul M \& Merike M (2006). On the indices of plant-plant competition and their pitfalls. Oikos 112: 149-155. https://doi.org/10.1111/j.0030-1299.2006.13379.x

SAS Institute (1998). Statistical Analysis System Institute: StatView Reference Manual. SAS Institute Cary NC

Sitters J, Edwards P J \& Venterink H O (2013). Increases of soil C, N and P pools along an Acacia tree density gradient and their effects on trees and grasses. Ecosystems 16: 347-357. doi: 10.1007/s10021-012-9621-4

Small E, Jurzysta M \& Nozzolillo C (1990). The evolution of hemolytic saponin content in wild and cultivated Alfalfa (Medicago sativa, Fabaceae). Economic Botany 44: 226-235

Soil Survey Laboratory Staff (1992). Soil Survey Laboratory Methods Manual. USDA-SCS. Soil Survey Investigations Report No: 42. Washington DC USA

Soliveres S, Maestre F T, Berdugo M \& Allan E (2015). A missing link between facilitation and plant species coexistence: nurses benefit generally rare species more than common ones. Journal of Ecology 103: 1183-1189. https://doi.org/10.1111/1365-2745.12447

Tilman D (1987). The importance of the mechanisms of interspecific competition. The American Naturalist 129: 769-774

Torres F A \& Montana C (2015). From facilitative to competitive interaction between Larrea tridentata and Cylindropuntia leptocaulis in the Southern Chihuahuan Desert. Journal of Vegetation Science 26: 68-79. https://doi.org/10.1111/jvs.12213

Wang P, Weiner J, Cahill J F, Zhou D W, Bian H F Song Y T \& Sheng L X (2014). Shoot competition, root competition and reproductive allocation in Chenopodium acuminatum. Journal of Ecology 102: 1688-1696. https://doi.org/10.1111/1365-2745.12313

(C) 2022 by the author(s). Published by Ankara University, Faculty of Agriculture, Ankara, Turkey. This is an Open Access article distributed under the terms and conditions of the Creative Commons Attribution (CC BY) license (http://creativecommons.org/licenses/by/4.0/), which permits unrestricted use, distribution, and reproduction in any medium, provided the original work is properly cited. 